\title{
PARTIAL MASCULINIZATION OF THE OVARY IN RATS TREATED WITH TESTOSTERONE PROPIONATE
}

\author{
LORE MARX ${ }^{*}$ \\ Department of Obstetrics and Gynecology, University of Michigan, Ann Arbor \\ ONE PLATE (FIVE FIGURES)
}

Evidence of hormonally induced sex reversal of the gonad has been furnished for cold blooded vertebrates and birds, but there is little known regarding such processes in mammals. Most authors attribute the gonadal changes in the freemartin to the heterosexual hormone. In the fowl, Dantchakoff ('36) and Willier, Gallagher and Koch ('37) obtained feminization of the testis by estrogens. In fishes and amphibians in some instances the sexual differentiation of the testis (Foote and Witschi, '39; Puckett, '40; Berkowitz, '41; Saunders and Rugh, '42) and in other cases that of the ovary (Witschi and Crown, '37; Gallien, '38; Puckett, '40 ; Foote, '40 ; '41; Eversole, '41) could be reversed by the respective heterosexual hormone. In the present communication the ability of male hormone to reverse to a certain degree the sex of the gonad is demonstrated in a mammal.

\section{MATERIAL}

Two young rats injected with testosterone propionate during June 1940 furnished ovaries the inner portions of which presented the histology of testes. This effect had never been noted before in rats treated in this laboratory with testosterone and testosterone esters. Various attempts were therefore made to reproduce this unusual result. Treatment of the

${ }^{1}$ Aaron Mendelson research assistant. 
two intersexual females had been carried out during a heat wave, and it was noted that untreated young rats and mice at this time underwent precocious sexual and somatic development. The reaction of the two experimental females to testosterone propionate may therefore have been enhanced by a hyperpituitary state. Puckett's findings in tadpoles likewise support the view that gonadotropic agents render the gonad responsive to sex hormones. Accordingly, young female rats were injected with various gonadotropic preparations in addition to testosterone propionate. ${ }^{2}$ Another group of rats was kept in a heated room while treatment with testosterone propionate was carried out. Only the latter method proved moderately successful, causing significant male changes in the ovaries of two out of twelve rats. The incidence of intersexuality is so low that much additional work must be done to determine the effective factors. The present report deals with the labile nature of the reproductive tissue and its dependence on sex hormones.

The two rats treated in June 1940 had been injected every other day with $\frac{1}{3} \mathrm{mg}$. testosterone propionate from the eighth day on and were sacrificed at 30 days. The two intersexes from the heated room had received three injections a week; one rat was treated from the fifth to the thirtieth day of life with the dose gradually increasing from $\frac{1}{2}$ to $2 \mathrm{mg}$., the other animal was treated from the sixth to the twenty-ninth day and the dose raised from $\frac{1}{2}$ to $1 \mathrm{mg}$. The temperature in this room varied between $80^{\circ}$ and $100^{\circ} \mathrm{F}$.

\section{HISTOLOGICAL CHANGES IN THE OVARY}

Injection of male hormone usually produces small ovaries consisting mainly of follicles, the theca and interstitium being reduced to fibrous tissue. In many follicles the granulosa shows signs of degeneration or the ovocyte is cleaved. The only specific effect is an inerease in the number of small apical tubes growing down from the suspensory ligament beside the mass of primary follicles. The author has previously de-

\footnotetext{
${ }^{3}$ The Schering Corporation kindly supplied Oreton for the new series of experiments.
} 
scribed these tubes in untreated and experimental rats (Marx, '41).

Enlargement of the rete is observed after either injection of male hormone or maintenance in warm environment $\left(80^{\circ}-\right.$ $100^{\circ}$ F.). Fusion of follicles is rarely seen in the cortex, but at the base of the ovary structures resembling seminiferous tubules (fig. 1) or follicles (fig. 2) often communicate with each other and with the rete. In control ovaries the granulosa in the medulla becomes reduced to a single layer and the antrum is narrow. After exposure to heat or male hormone the medullary follicles are seen to have larger lumina, are lined by the same epithelium as the rete and seem to take part in its formation. If the cumulus is preserved, it projects as a papilla into the sinuses. Figure 2 shows three communicating follicles of a testosterone-treated rat. The cumuli have disintegrated as is common in the medulla and the ovocytes are free within the lumen.

The tubules of intersexual ovaries, in contrast to the apical tubes, are derived from large or medium-sized follicles. In ovaries slightly affected by testosterone, the transformation involves only a few scattered follicles. Such a finding does not prove the effectiveness of the treatment, as single bodies resembling poorly differentiated seminiferous tubules have been observed in continuous-estrus rats, heat controls and also in an untreated wild female (unpublished observation). The most marked effect obtained by treatment with male hormone at an elevated temperature was the transformation of a whole group of follicles into tubules, so that this portion of the ovary gave the impression of testis tissue. In the two 4-week-old rats treated in summer 1940, a testis-like region extended from the inner cortex to the broad ligament (fig. 4). Three females in which the injections were started at the same time but which were sacrificed 2 and 4 weeks later possessed only a few masculinized follicles at the base of the ovary. They were situated between the normal follicles and showed signs of regression. In the heated room, seven out of twelve injected rats developed tubules. The tubules were better differentiated 
and closer together than in females injected at room temperature or in "heat" controls. The masculinization reached a high degree in two of these seven animals; in one instance there was a small testis-like area (fig. 3 ), in the other numerous tubules distributed between the follicles.

The initial stage in the transformation of a graafian follicle into a tubule is a swelling of the granulosa cells and their nuclei. This type of follicle is also seen in ovaries that have not otherwise responded to the injection of testosterone propionate during summer or in the heated room. The change is most conspicuous where it affects only part of the follicular wall (fig. 5). The nuclei of the enlarged cells stain faintly and the cytoplasm is quite clear. If the transformation is complete, it involves the entire follicle (fig. 1) while the inner rows of the granulosa with the ovocyte desquamate into the antrum. In the two or three rows of epithelium which remain in place the nuclei are arranged basally and long strands of cytoplasm stretch into the lumen. Figure 1 shows the basal border of the masculinized region where a moderate amount of connective tissue enters from the broad ligament. The similarity to testis-tissue is therefore not as great as in the central part of the ovary (fig. 4) where the tubules are closely packed.

\section{DISCUSSION}

Of special interest in the case of the intersexual rat ovaries is the fact that the abnormality occurs so late in the developmental stage. In none of the rats sacrificed before the age of 25 days could an ovariotestis be found. Since the transformed ovaries are histologically well differentiated, they offer an excellent opportunity to study homologies between testis and ovary. In contrast to the laborious methods of embryology, in sections of the month-old-rat ovaries each structure, so to speak, told its own story. Elements similar to seminiferous tubules arise from ovarian follicles; hence the granulosa cells seem to be homologous to Sertoli cells and spermatogonia and have retained germ cell potentiality. The ovocytes can be compared to the giant cells of the adolescent testis, 
often termed ovocytes by old anatomists. The theca folliculi, in transformed portions of the ovary, becomes a fibrous capsule around the tubules. The interstitium is the same whether it is situated in the space between normal or trans. formed follicles.

In so far as the histological aspect permits a conclusion regarding the functional activity, the fibrous state of theca and interstitium indicates that the intersexual ovaries exert no endocrine function. ${ }^{3}$ It may be assumed that the injected male hormone was responsible for the follicular changes noted.

\section{SUMMARY}

The transformation of follicles into seminiferous tubules was studied by examining a large number of rat ovaries. The initial stages of this change were found to occur under various conditions, but ovaries containing well differentiated testislike areas were rare and occurred only among young females kept at elevated temperature while being injected with the male hormone.

\section{LITERATURE CITED}

Albert, S., ANd H. Selye 1942 The gonadotropie effect of various steroid compounds. Fed. Proc. Amer. Soc. Exp. Biol., vol. 1, p. 29. (Abstract.)

Berkowitz, P. 1941 The effect of estrogenic substances in the fish (Lebistes reticulatus). J. Exp. Zool., vol. 68, pp. 233-240.

Conner, G. W. 1938 The sites of formation of estrogenic substances in the animal body. Physiol. Reviews, vol. 18, pp. 154-172.

Cutuly, E. 1941 Androgens and spermatogenesis in rats. Anat. Ree, vol. 79, suppl. 2, p. 16. (Abstract.)

DANTChakofr, VERA 1931 Sur la capacité de la folliculine à transformer, chez la poule, le rudiment gonadique droit (testicule potentiel) en ovaire. Compt. rend. Soc. de Biol., vol. 122, pp. 168-169.

DEANESLY, RUTH 1938 The androgenic activity of ovarian grafts in castrated male rats. Proc. Roy. Soe. London B., vol. 126, pp. 122-135.

Dubreuil, G., G. JANNENEY AND P. Collin 1939 Follicules kystiques, follicules plissés hyperplasiés; leur intèrêt pour la permanence de la glande thécale ovarienne. Compt. rend. Soc. de Biol., vol. 132, pp. 579-581.

\footnotetext{
${ }^{3}$ The evidence for the secretion of estrogen by theca and interstitium is reviewed by Corner ('38). See also Zondek ('31); Selye and Collip ('33); Dubreuil, Janneney and Collin ('40). A masculinizing influence of theca and interstitium has been reported by Guyénot and Naville-Trolliet ('36); Deanesly ('38); Greene and Burrill ('39); Marx and Bradbury ('40).
} 
EVERsole, W. J. 1941 The effects of pregnenilone and related steroids on sexual development in fish (Lebistes reticulatus). Endocrinol, vol. 28, pp. 603-606.

Foore, C. L. 1940 Response of gonads and gonaducts of Amblystoma larvae to treatment with sex hormones. Proe. Soc. Exp. Biol. and Med., vol. 43 , pp. 519-523.

1941 Modification of sexual development in the marbied salamander by administration of synthetic sex hormones. J. Exp. Zool., vol. 86, pp. 291-313.

Foote, C. L., ANd E. Witschi 1939 Effect of sex hormones on the gonads of frog larvae (Rana clamitans). Sex inversion in females; stability in males. Anat. Rec., vol. 75, pp. 75-83.

GAllien, L. 1938 Action masculinisante du propionate de testostérone dans la différentiation du sexe, chez Rana temporaria L. Bull. biol. franc., vol. 72, pp. 269-296.

Greene, R. R., AND M. W. Burrili 1939 Experimental intersexuality; masculinization of female rats by postpartum treatment with anteriorpituitary-like hormone. Proe. Soc. Exp. Biol. and Med., vol. 40, pp. 514-516.

Gryénct, E., AND MMe. Navilite-Trolliet 1936 Masculinisation provoqué de femelles de cobaye (Extraits hypophysaires et urine de femme enceinte). Revue suisse de Zool., vol. 43, pp. 415-454.

MARX LoRE 1941 Replacement of ovocytes in the ovary of normal and hormoneinjected young rats. Anat. Rec., vol. 79, pp. 115-131.

MARX, LoRE, AND J. T. BRADBURY 1940 Correlation of ovarian histology and intersexuality of the genital apparatus, with special reference to APL-treated infantile rats. Anat. Rec., vol. 78, pp. 79-103.

Nelson, W. O. 1941 Renewal of sperm formation in hypophysectomized rats. Anat. Rec., vol. 79, suppl. 2, p. 48. (Abstract.)

PUCKETT, W. O. 1940 Some effects of erystalline sex hormones on the differentiation of the gonads of an undifferentiated race of Rana eatesbiana tadpoles. J. Exp. Zool., vol. 84, pp. 39-52.

Silnders, Grace, ANd R. Rugh 1942 The effect of pregnenilone on the genital system of the immature salamander, Amblystoma punctatum. Anat. Rec., vol. 82, p. 488. (Abstract.)

Selye, H., AND J. B. Coluip 1933 Production of exclusive thecal luteinization and continuous estrus with anterior-pituitary-like hormone. Proc. Soc. Exp. Biol. and Med., vol. 30, pp. 647-649.

Willier, B. H., T. F. Gallagher AND F. C. KoCH 1937 The modification of sex development in the chick embryo by male and female sex hormones. Physiol. Zool., vol. 10, pp. 101-122.

Witschr, E., AND E. N. CRown 1937 Hormones and sex determination in fishes and in frogs. Anat. Ree., vol. 70, suppl. 1, pp. 121-122. (Abstract.)

ZoxDEK, B. 1931 Die Hormone des Ovariums und des Hypophysenvorderlappens. J. Springer, Berlin, Germany. 

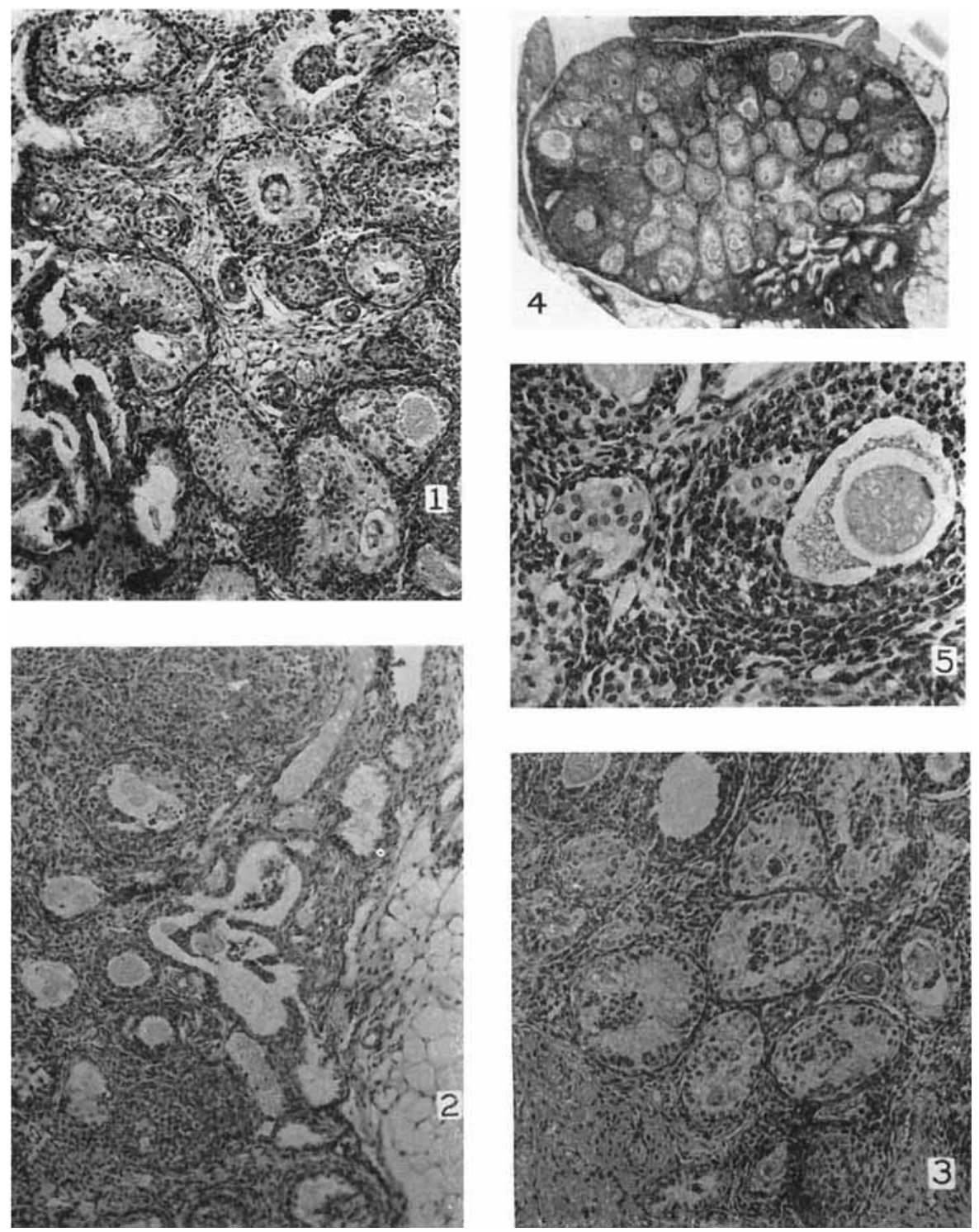

1 Basal region of the intersexual ovary of a 30-day-old rat, injected from the eighth day during a heat wave with $\frac{1}{3} \mathrm{mg}$. testosterone propionate every other day.

2 Basal region of the ovary of a 25 -day-old rat, injected from the fourth day three times a week with $0.5 \mathrm{mg}$. testosterone propionate. Three large follicles communicate witl one another and with the rete.

3 Group of tubules in the ovary of a 25-day-old rat, maintained in a hot room and injected three times a week with testosterone propionate from the sixth day on. For the first three injections $0.5 \mathrm{mg}$. was given, then the dose was doubled.

4 Section through the intersexual ovary from which figure 1 was taken.

5 Section through the ovary of a 23 -day-old rat, injected three times a week with $0.5 \mathrm{mg}$. testosterone propionate from the seventh day on. In the large follicle on the right a portion of the granulosa consists of transformed cells. In two communicating and one single follicle at the lower left all granulosa cells are changed. 